March 2013, Volume 3, No. 1 Pages (110 - 122)

\title{
A Field Study on the Job Satisfaction of Teaching Board Members of Physical Education Faculties in Egypt in Light of Performance Quality
}

\author{
Nesreen Mohammed Eid El-Sharqawy*, Samah Mohammed Amin Halawa** \\ * Teacher in Teaching Methods \& practical education Department, Physical Education Faculty, Menoufia \\ University. \\ ** Teacher in water sports and fights Department, Physical Education Faculty, Menoufia University.
}

\begin{abstract}
This research aim to: study the job satisfaction of teaching board members of Physical Education Faculties - in light of performance quality incentive against salary increase. METHODS: The two researchers used the descriptive method, and research society represented in 519 members of teaching board of Physical Education Faculties in Egypt as follows: 204 teacher, 171 assistant professors, 103 professors, and 41 full-time professors. The research sample was selected randomly.

The data gathered was represented in: A scale to study the job satisfaction of teaching board members of Physical Education Faculties. The scale consisted of 77 phrases, distributed on 5 dimensions which are :(work environment - salaries and incentives - performance quality versus salary increase - work relationships - and promotion system).

The statistical unalysis was represented in: Arithmetic means - standard deviation - the repetitions - the percentage rates - The correlation coefficient - $(T)$ Test to calculate differences - Cronbach alpha.

The most important results of the research were that:

- Job satisfaction of teaching board members of Physical Education Faculties studied in the research was weak and rated $36.38 \%$.

- Work environment axis came in the 1st place of job satisfaction of teaching board members rated $36.37 \%$, and in the 5th and last place came salaries and incentives rated $17.32 \%$.

Recommendations:

- Implementing strategy to improve job satisfaction to the teaching board members of Physical Education faculties in Egypt.
\end{abstract}

\section{Introduction and Research Problem:}

$\mathrm{T}$ he university occupies the place of the society thinking mind, it is responsible for major tasks in the scientific, professional and technological fields. The university has basic jobs of which the most important is the professional and academic preparation of its students, as it prepares the future generations and opens future horizons in front of them in order to bear the responsibility in different positions. (1:680)

The teaching board member represents the corner stone in the educational process for being the effective instrument that enables the university to perform its responsibility and deliver its mission to modernize education, serve society and advance towards the scientific progress. Therefore, university teaching profession is considered one of the finest professions in all societies, the university exerts a huge effort in preparing and training the university professor according to special policies and programs that continue for long years of effort, research and thinking that are crowned in the end by obtaining the highest scientific degrees. $(2: 3)$

In order to perform his role towards achieving scientific and educational aims, the teaching board member has to be satisfied about his work as this satisfaction will encourage him to give and exert sincere and serious effort in work. The 
study of both Be Castro \& Gold assured that the imbalanced relation between the person and his professional environment results from his discontent of his work environment. (3: 200).

Whether this satisfaction is complete or partial concerning certain aspects of teaching board member, it is for granted that work success whatever it was requires achieving high degree of comfort in this work, especially in the field of university teaching. The study of Bhell Agyris assures, as it concluded that the most satisfied workers tend to achieve higher levels of productivity, and are expected to work effectively. (4: 684)

The job satisfaction of teaching board member is considered one of the prominent factors that affects his work, thus, this study came to focus on studying job satisfaction and its relation with some variables of teaching board members. As the two researchers see that the study subject is important because it studies variables associated with the university professor. Some studies concluded that there is a positive relation between job satisfaction and the motivation like studies of Likert, and Taylor \& Weiss, while others showed that this relation does not exist in a direct way like that of Vroom, Baird and Fisher. (5: 141)

Proceeding from the importance of teaching board member in the university and the role of the university in creating the suitable conditions inside would certainly help to increase its effectiveness, modernize it and improve the scientific performance that achieve the required development. Job satisfaction of teaching board members is considered one of the prominent factors that affect his giving in work, therefore, this research came to shed the light on the job satisfaction and its relation with some variables of teaching board members. The two researchers see that the study subject gains its importance from studying the variables that are associated with the university professors especially after the incentive had increased.

\section{Research importance:}

1- Despite the numerous studies about this subject, this study is considered the first study in Egypt of its kind to measure the level of job satisfaction of teaching board members after the financial had increased.
2- The results of this study are expected to provide the officials with important information about the bases of treating the teaching board members and the ways to satisfy them to improve their performance and build new strategies about dealing with teaching board members.

\section{Research questions:}

1- What is the level of job satisfaction of teaching board members of Physical Education Faculties?

2- Are there statistical shown differences in the level of job satisfaction of teaching board members in the following variables (age kind -years of experience - social status scientific degree)?

3- What are the important elements that affect job satisfaction of teaching board members of Physical Education Faculties?

\section{Research Terms:}

Job Satisfaction: a positive feeling that make the individual eager to work, and motivate him to achieve his ambitions, desires and professional preferences and that match with what he wants from his work and what he gets in reality. (Procedural definition)

\section{Research procedures:}

\section{First: Research Method:}

The two researchers used the descriptive method because it suits the nature of the research.

\section{Second: Research Society and Sample:}

Research society consisted of teaching board members of Physical Education Faculties of Egyptian universities and was as follows: (85) teaching board members for pilot study and (519) for the basic study.

\section{Third: Scale designing:}

Measuring the degree of the job satisfaction of the teaching board members of Physical Education faculties in Egyptian universities.

\section{Forming Scale Phrases:}

Proceeding from research title, and based on the scientific references and previous studies (3), (1) and (2), along with experts' opinions and the two researchers' experience in the field of university teaching, the phrases were selected to express teaching board members' opinions 
towards job satisfaction. The two researchers used Likert method of the 5 weights as it suits the research.

Simplicity and clarity were taken into consideration in the method, where teaching board members express their opinions towards application phrases according to three-graded scale (satisfied / to some extent / unsatisfied).

The total degree was calculated by adding the tested degrees in the different three groups of the scale where the total ranged from 77 to 231 . The high degree indicates job satisfaction, while the low one indicates dissatisfaction.

\section{Honesty:}

The external honesty of the tool was checked through displaying it on a committee of experts and specialists in order to show the validity range of each clause concerning its suitability to the field and the suitability of its form. The number of experts were (7), and the two researchers adopted the phrases that were approved by $70 \%$ or more of the judges.

\section{Internal Consistency Honesty:}

The honesty of the internal consistency was calculated on a pilot sample of research society, the value of calculated " $\mathrm{R}$ " of some phrases was more than the value of table " $\mathrm{R}$ " which reached $0.05=0.178$ at morale level, which indicates a statistical shown correlation between these phrases and the dimensions where they belong which indicates the honesty of these phrases to measure what they were put for.

\section{Stability:}

The two researchers elicited stability by using the half fractionate of scale phrases and cronbahk alpha They found that there is a statistically shown correlation between the phrases of each dimension which indicates axis stability with its phrases where the correlation coefficient reached in order: $917,0.792,0.856$ and 0.444 for each axis. And cronbahk alpha reached $0.786,0.917,0.856$ and 0.444 .

\section{Study Application Steps:}

The two researchers applied the pilot study in the period from $28 / 2 / 2010$ to $28 / 3 / 2010$, and applied the scale to precede the scientific interactions for it. After being assured of the scale scientific interactions, the scale was applied on the basic sample of teaching board members of Egyptian universities in the period from $1 / 4 / 2010$ to $29 / 4 / 2010$.

The applications were marked through scale mark key to put the digital value of each application and to collect the raw degree in order to handle it statistically.

\section{The Statistical Treatments:}

The two researchers used the statistical program SPSS.

\section{Displaying and Discussing the Results:}

The following is answering the research questions through analyzing the results reached by the two researchers.

\section{The Answer of the research First Question:}

What is the level of job satisfaction of teaching board members of Physical Education faculties?

To answer this question, the two researchers extracted the arithmetic mean, the frequency, the percentages and the order to show the importance of the five axes through the answer of teaching board members. Table (1) shows the first axis: Work Conditions \& Environment. 
Table (1)

The relative weight and the relative importance of the first axis

"Work Conditions and Environment" $\quad \mathrm{N}=519$

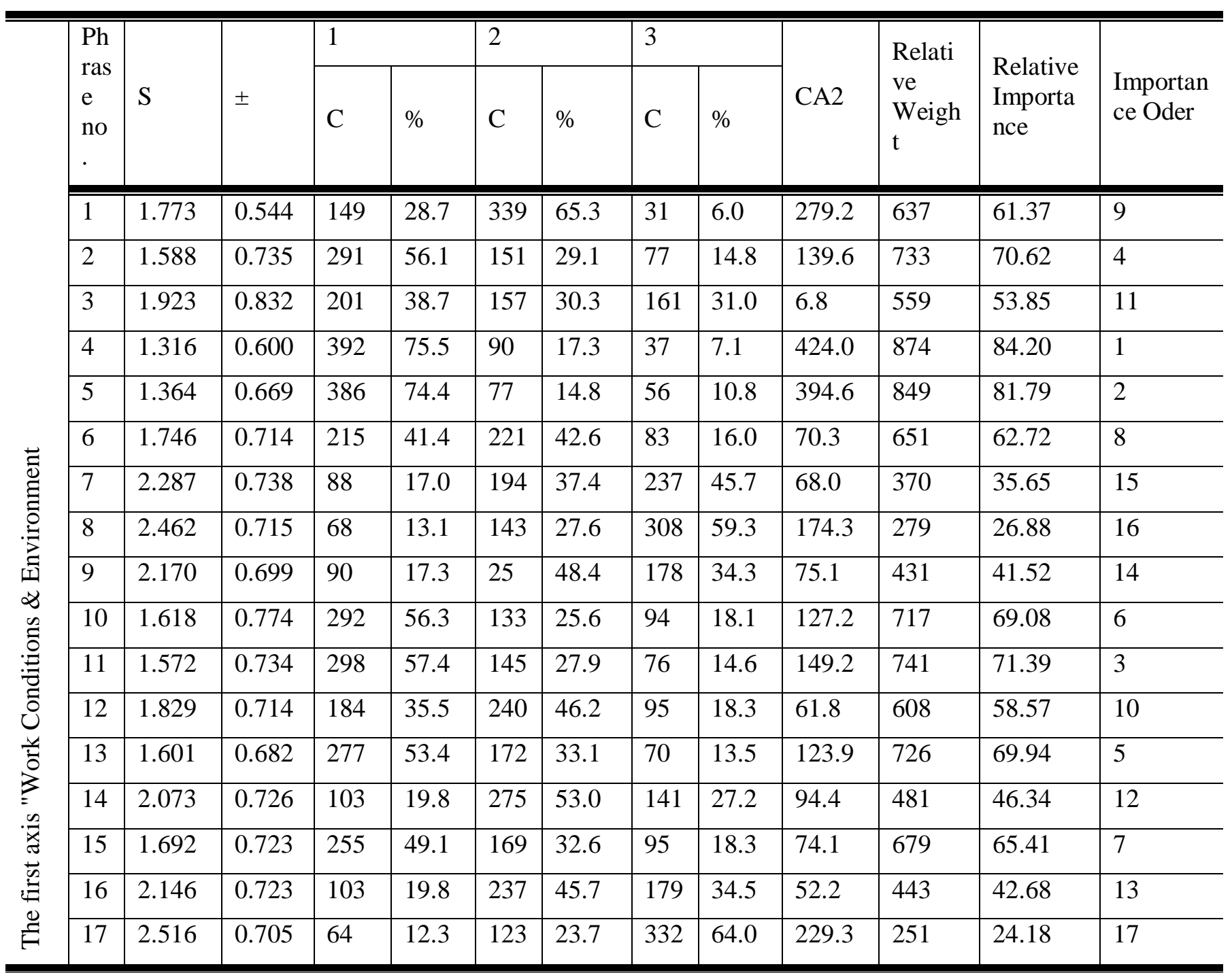

The table value of (CA) at morale level $0.05=5.991$

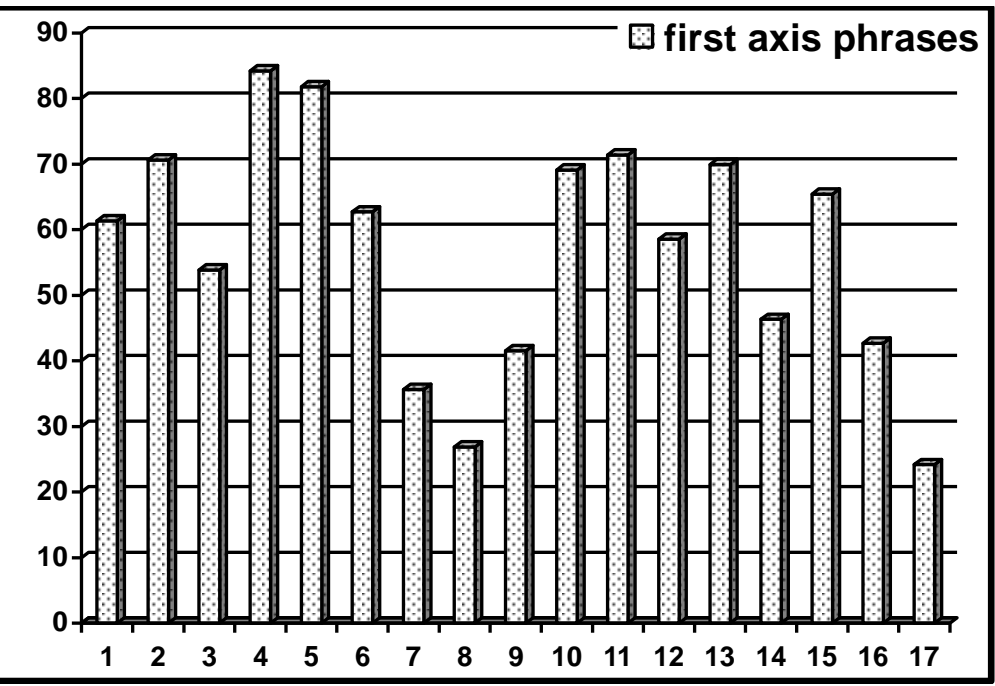

Figure (1) "Work Conditions and Environment" 
Table (1) and figure (1) shows that the phrase no. (17) which states that "I do not think in quitting work in the present time" came in the first place rating ( $84.2 \%, 75.5 \%$ of teaching board members answered this phrase with satisfied) while $7.1 \%$ did not approve on that, the phrase no. (5) Which stated that "my job fits my personal abilities and experience" came in the $2^{\text {nd }}$ place $(81.4 \%, 74.4 \%$ of teaching board members answered this phrase were satisfied) while $16.0 \%$ did not approve on that. On the $3^{\text {rd }}$ place the phrase no (11) which states that "I feel that I achieve myself satisfaction on performing my work" the phrase rating $71.3 \%$. on the other hand and on the $6^{\text {th }}$ place the phrase no (6)which states that "I feel satisfied with the policies and the administrative process in my work environment" $62.7 \%$ however, this result did not match other studies by(Samir Nasr El din-2006) who reported less approval on average level.

\section{Second: salaries and incentives axis}

Table (2)

The relative weight and the relative importance of second axis phrases "salaries and incentives" $\mathrm{N}=519$

\begin{tabular}{|c|c|c|c|c|c|c|c|c|c|c|c|c|c|}
\hline & \multirow{2}{*}{$\begin{array}{l}\text { Phr } \\
\text { ase } \\
\text { no. }\end{array}$} & \multirow{2}{*}{$\mathrm{S}$} & \multirow{2}{*}{ \pm} & \multicolumn{2}{|l|}{1} & \multicolumn{2}{|l|}{2} & \multicolumn{2}{|l|}{3} & \multirow{2}{*}{ CA2 } & \multirow{2}{*}{$\begin{array}{l}\text { Relativ } \\
\text { e } \\
\text { Weight }\end{array}$} & \multirow{2}{*}{$\begin{array}{l}\text { Relative } \\
\text { Importan } \\
\text { ce }\end{array}$} & \multirow{2}{*}{$\begin{array}{l}\text { Importan } \\
\text { ce Oder }\end{array}$} \\
\hline & & & & $\mathrm{C}$ & $\%$ & $\mathrm{C}$ & $\%$ & $\mathrm{C}$ & $\%$ & & & & \\
\hline \multirow{6}{*}{ 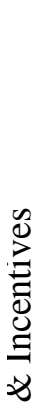 } & 1 & 1.339 & 535.0 & 16 & 3.1 & 144 & 27.7 & 359 & 69.2 & 347.3 & 862 & 83.04 & 2 \\
\hline & 2 & 1.455 & 687.0 & 58 & 11.2 & 120 & 23.1 & 341 & 65.7 & 255.8 & 802 & 77.26 & 9 \\
\hline & 3 & 1.364 & 573.0 & 25 & 4.8 & 139 & 26.8 & 355 & 68.4 & 324.8 & 849 & 81.79 & 4 \\
\hline & 4 & 1.617 & 587.0 & 28 & 5.4 & 264 & 50.9 & 227 & 43.7 & 186.3 & 718 & 69.17 & 12 \\
\hline & 5 & 1.179 & 422.0 & 8 & 1.5 & 434 & 83.6 & 77 & 14.8 & 604.4 & 945 & 91.04 & 1 \\
\hline & 6 & 1.403 & 571.0 & 22 & 4.2 & 165 & 31.8 & 332 & 64.0 & 278.3 & 829 & 79.87 & 5 \\
\hline$\widehat{\exists}$ & 7 & 1.449 & 606.0 & 31 & 6.0 & 171 & 32.9 & 317 & 61.1 & 236.4 & 805 & 77.55 & 8 \\
\hline $\mathscr{\infty}$ & 8 & 1.434 & 657.0 & 48 & 9.2 & 129 & 24.9 & 342 & 65.9 & 266.6 & 813 & 78.32 & 7 \\
\hline 発 & 9 & 1.484 & 630.0 & 38 & 7.3 & 175 & 33.7 & 306 & 59.0 & 207.6 & 787 & 75.82 & 10 \\
\hline $\overrightarrow{\tilde{0}}$ & 10 & 1.408 & 663.0 & 51 & 9.8 & 110 & 21.2 & 358 & 69.0 & 306.8 & 826 & 79.58 & 6 \\
\hline$\stackrel{D}{\Omega}$ & 11 & 1.526 & 765.0 & 87 & 16.8 & 99 & 19.1 & 333 & 64.2 & 222.4 & 765 & 73.70 & 11 \\
\hline$\Xi$ & 12 & 1.343 & 561.0 & 23 & 4.4 & 132 & 25.4 & 364 & 70.1 & 350.6 & 860 & 82.85 & 3 \\
\hline
\end{tabular}

The table value of (CA2) al morale level $0.05=5.991$

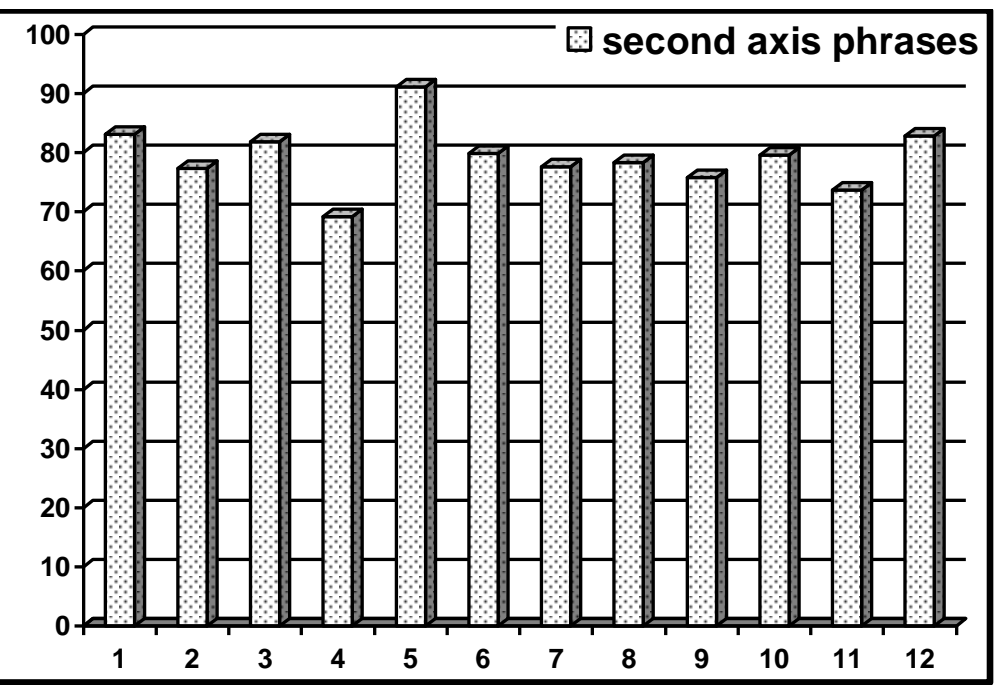

Figure (2) "salaries and incentives" 
Table (2) and figure (2) shows that the phrase no. (5) which is "I felt satisfied about salaries and incentives increase in my job" came in the first place rating $(91.01 \%, 83.6 \%$ of teaching board members answered moderately on the phrase), while $14.8 \%$ did not approve on it, The phrase no. (4) which is "the income I get is considered relatively high compared with the exerted effort" came in $12^{\text {th }}$ and last place rating $(69.17 \%, 50.9 \%$ of teaching board members answered moderately on the phrase) while $43.7 \%$ did not approve it. In the phrase $(9,10)$ " participation in the local and international conferences", the degree of satisfaction was high rating $(75.8 \%$ \& $79.5 \%)$.This result was markedly different from those reported by Haekal Taha 2007,

Third: Performance Quality Axis versus Salary Increase

Table (3)

The relative weight and the relative importance of third axis phrases "Performance Quality versus Salary Increase" $\quad \mathrm{N}=519$

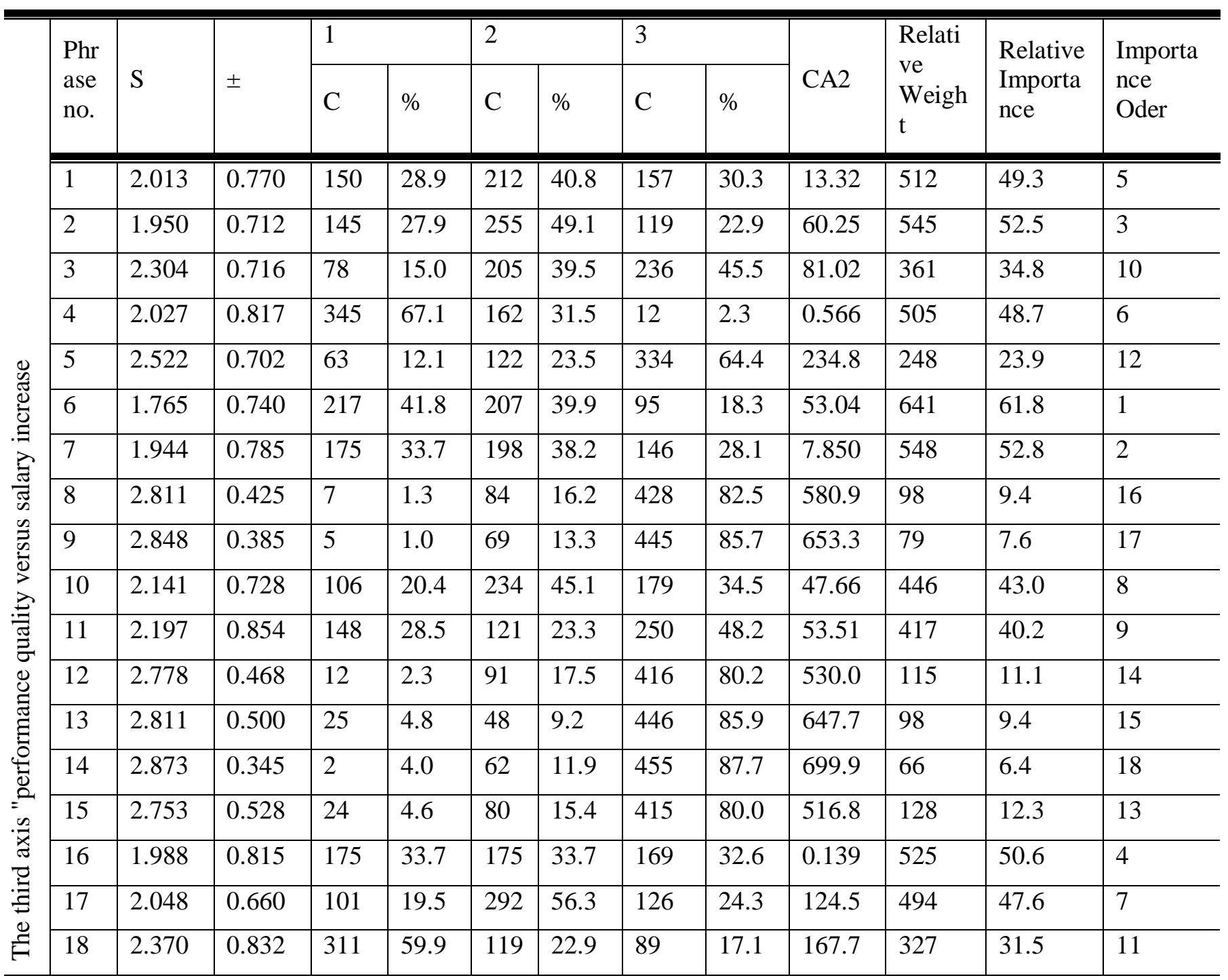

The table value of (CA2) at morale level $0.05=5.991$ 


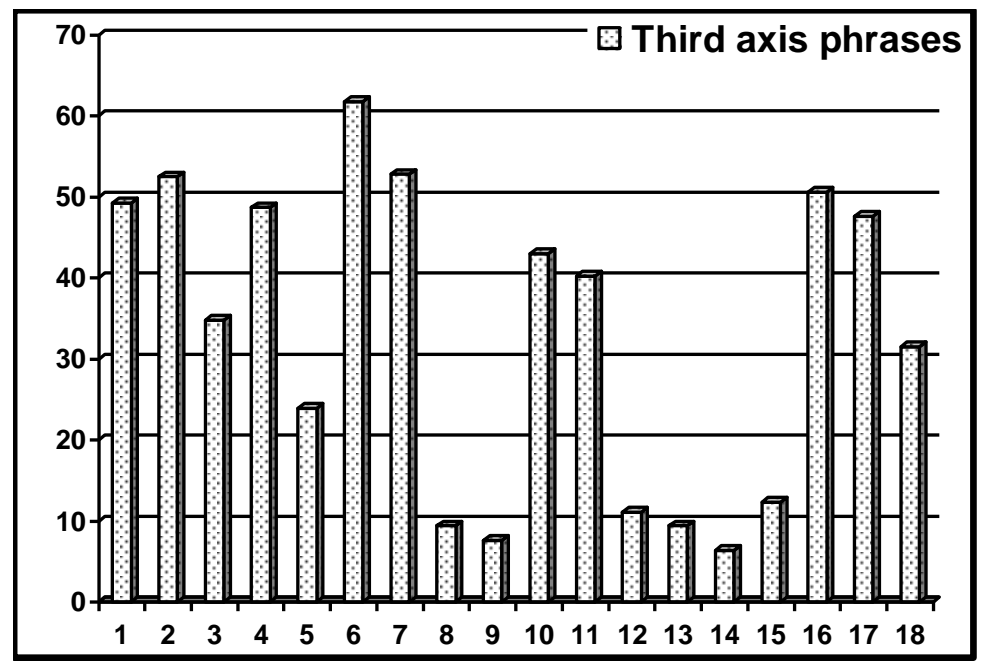

Figure (3) "Performance Quality versus Salary Increase"

Table (3) and figure (3) shows that the phrase no. (6) which is "the reward of scientific research supervision must increase" came in the first place rating $(61.8 \%, 41.8 \%$ of teaching board members answered the phrase were satisfied) while $18.3 \%$ did not approve that. The
Table (4)

phrase no. (14) which is "cashing in 4 payments annually is considered suitable" came in the $18^{\text {th }}$ and last place rating $(6.4 \%, 87.7 \%$ of teaching board members answered the phrase were unsatisfied) while $4 \%$ approved that.

Fourth: Work Relations Axis.

The relative weight and the relative importance of the Fourth axis phrases "Work Relations" $\mathrm{N}=519$

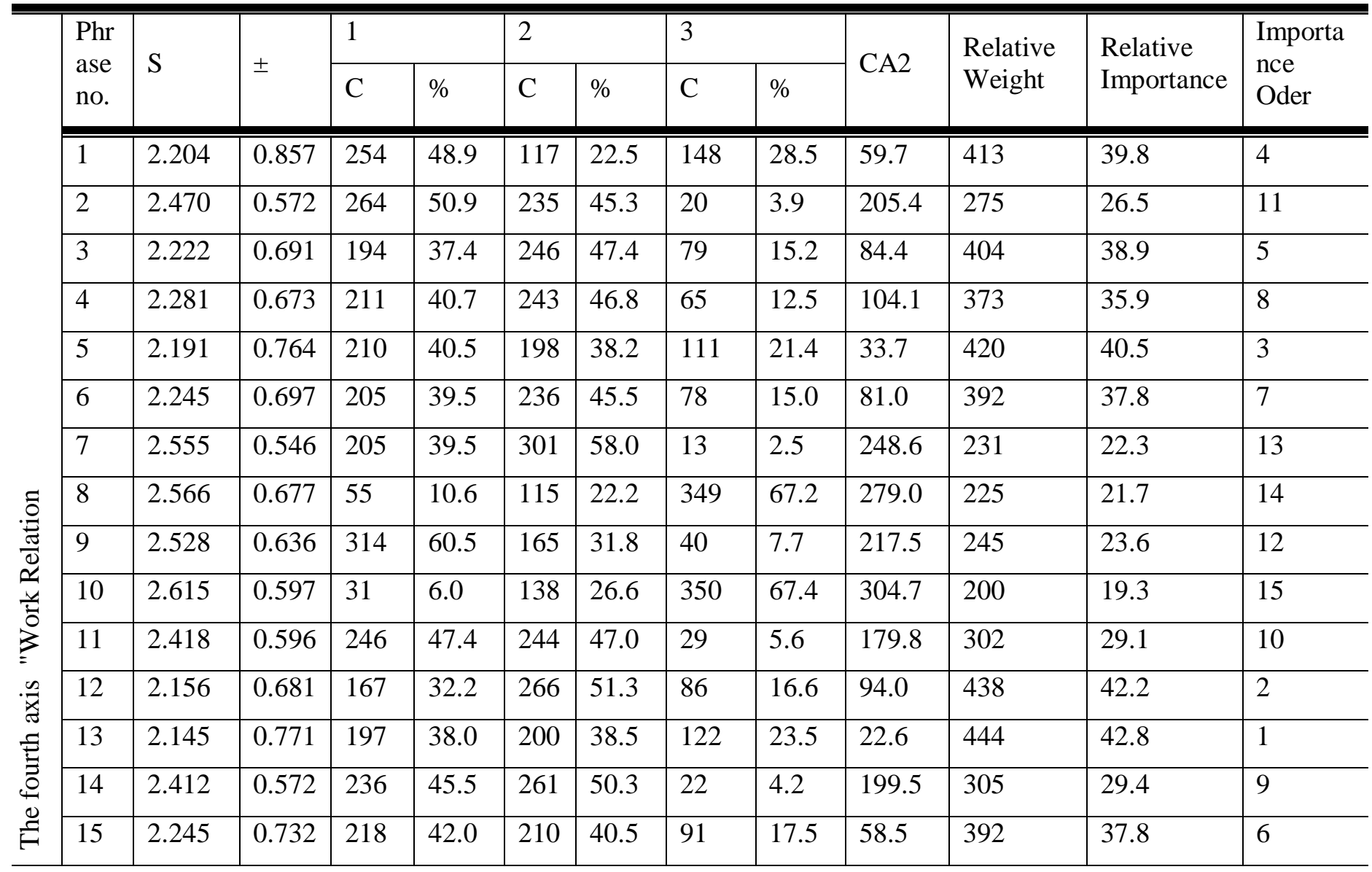

The table value of (CA2) at morale level $0.05=5.991$ 


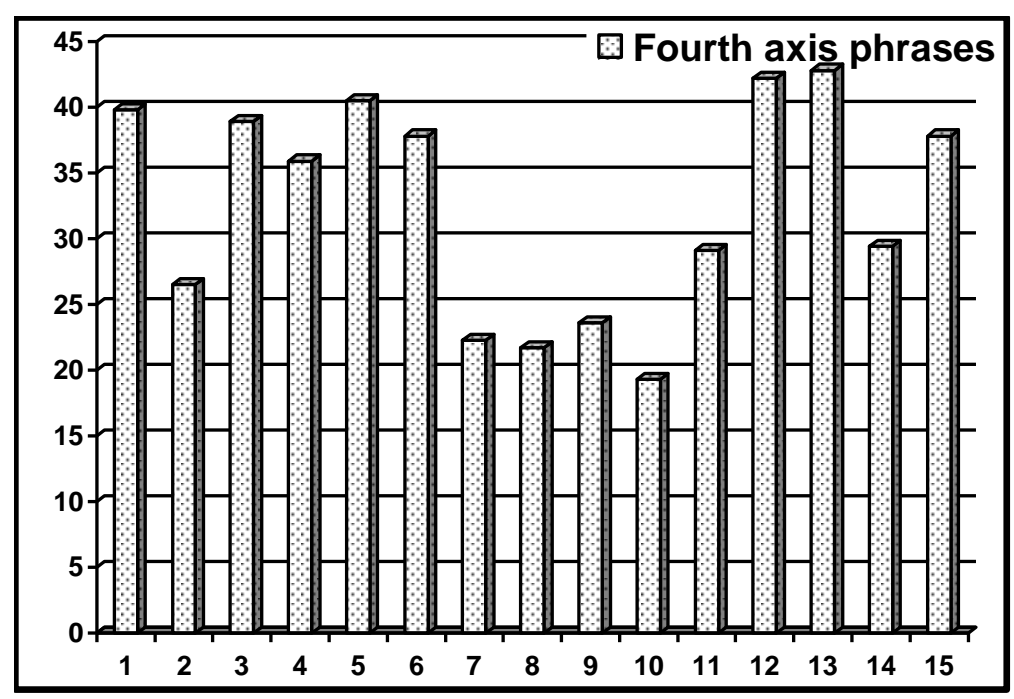

Figure (4) "Work Relations"

Table (4) and figure (4) shows that the phrase no. (13) Which is "I feel satisfied about the department assistant staff" came in the first place rating $(42.8 \%, 38.0 \%$ of teaching board members answered this phrase were satisfied) while $23.5 \%$ did not approve that, The phrase no. (10) which is "head of department is worthy of taking the responsibility" came in the $15^{\text {th }}$ and last place rating $(19.3 \%, 6.0 \%$ of teaching board members answered this phrase were satisfied), while $67.4 \%$ did not approve that.

Fifth: Promotion System Axis Table (5)

The relative weight and the relative importance of the fifth axis Phrases "Promotion System" $\mathrm{N}=519$

\begin{tabular}{|c|c|c|c|c|c|c|c|c|c|c|c|c|c|}
\hline \multirow{2}{*}{\multicolumn{2}{|c|}{$\begin{array}{l}\text { Phr } \\
\text { ase } \\
\text { no. }\end{array}$}} & \multirow{2}{*}{$\mathrm{S}$} & \multirow{2}{*}{ \pm} & \multicolumn{2}{|l|}{1} & \multicolumn{2}{|l|}{2} & \multicolumn{2}{|l|}{3} & \multirow{2}{*}{ CA2 } & \multirow{2}{*}{$\begin{array}{l}\text { Relative } \\
\text { Weight }\end{array}$} & \multirow{2}{*}{$\begin{array}{l}\text { Relative } \\
\text { Importance }\end{array}$} & \multirow{2}{*}{$\begin{array}{l}\text { Importanc } \\
\text { e Oder }\end{array}$} \\
\hline & & & & $\mathrm{C}$ & $\%$ & $\mathrm{C}$ & $\%$ & $\mathrm{C}$ & $\%$ & & & & \\
\hline & $\overline{11}$ & 1.909 & 0.629 & 128 & 24.7 & 310 & 59.7 & 81 & 15.6 & 196.1 & 566 & 54.5 & 3 \\
\hline & 2 & 2.249 & 0.659 & 64 & 12.3 & 262 & 50.5 & 193 & 37.2 & 116.8 & 390 & 37.6 & 10 \\
\hline & 3 & 2.329 & 0.619 & 42 & 8.1 & 264 & 50.9 & 213 & 41.0 & 156.3 & 348 & 33.5 & 11 \\
\hline & 4 & 2.071 & 0.675 & 101 & 19.5 & 280 & 53.9 & 138 & 26.6 & 103.2 & 482 & 46.4 & 7 \\
\hline & 5 & 2.451 & 0.613 & 33 & 6.4 & 219 & 42.2 & 267 & 51.4 & 176.6 & 285 & 27.5 & 14 \\
\hline & 6 & 2.245 & 0.708 & 82 & 15.8 & 228 & 43.9 & 209 & 40.3 & 72.8 & 392 & 37.8 & 9 \\
\hline & 7 & 2.372 & 0.742 & 82 & 15.8 & 162 & 31.2 & 275 & 53.0 & 108.7 & 326 & 31.4 & 12 \\
\hline$\frac{\pi}{9}$ & 8 & 2.071 & 0.754 & 130 & 25.0 & 222 & 42.8 & 167 & 32.2 & 24.8 & 482 & 46.4 & 6 \\
\hline 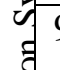 & 9 & 2.096 & 0.702 & 111 & 21.4 & 261 & 50.3 & 147 & 28.3 & 70.9 & 483 & 46.5 & 5 \\
\hline 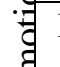 & 10 & 2.187 & 0.734 & 100 & 19.3 & 222 & 42.8 & 197 & 38.0 & 48.0 & 422 & 40.7 & 8 \\
\hline $\begin{array}{l}5 \\
0\end{array}$ & 11 & 1.844 & 0.784 & 206 & 39.7 & 188 & 36.2 & 125 & 24.1 & 20.9 & 600 & 57.8 & 2 \\
\hline$=$ & 12 & 1.994 & 0.830 & 180 & 34.7 & 162 & 31.2 & 177 & 34.1 & 1.1 & 522 & 50.3 & 4 \\
\hline ฮู & 13 & 1.613 & 0.780 & 297 & 57.2 & 126 & 24.3 & 96 & 18.5 & 135.9 & 720 & 69.4 & 1 \\
\hline 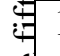 & 14 & 2.493 & 0.627 & 37 & 7.1 & 189 & 36.4 & 293 & 56.5 & 191.6 & 263 & 25.3 & 15 \\
\hline ह & 15 & 2.426 & 0.685 & 58 & 11.2 & 182 & 35.1 & 279 & 53.881 & 141.9 & 298 & 28.7 & 13 \\
\hline
\end{tabular}

The table value of $(\mathrm{Ca} 2)$ at morale level $0.05=5.991$ 


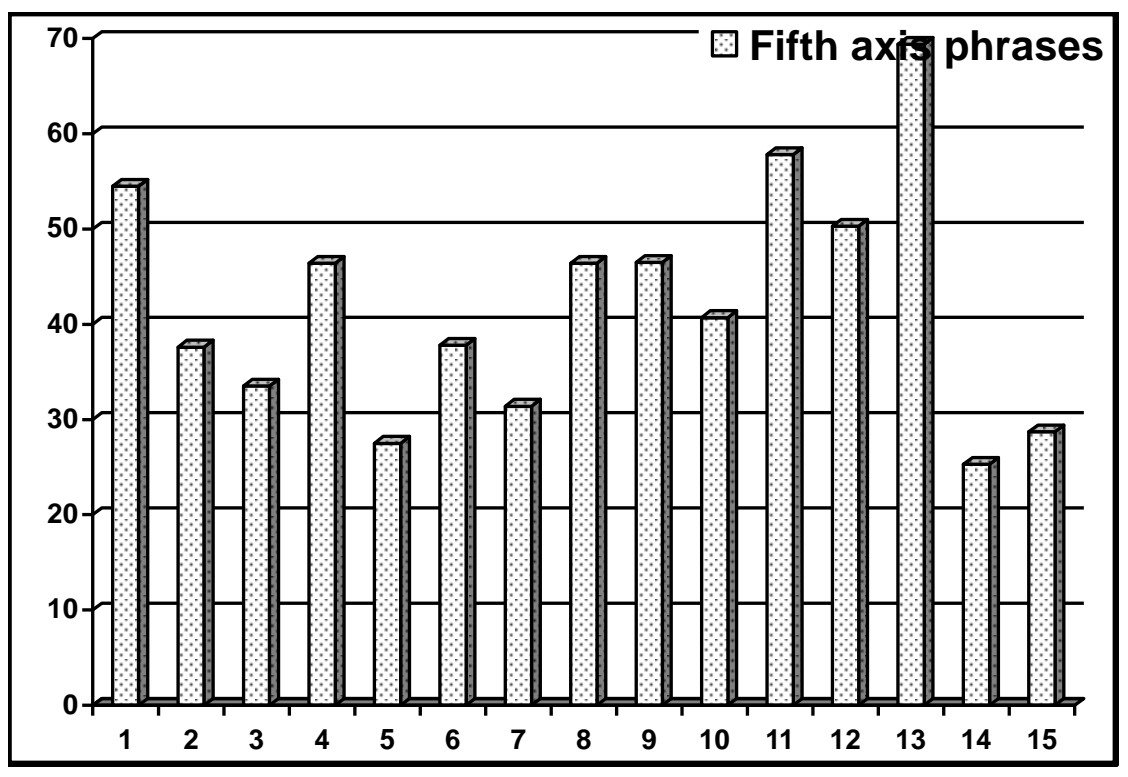

Figure (5) "Promotion System"

Table (5) and figure (5) shows that phrase no. (13) Which is "I feel satisfied about my job grading" came in the first place rating $(69.4 \%$, $57.2 \%$ of teaching board members answered the phrase were satisfied), while $18.5 \%$ did not approve that. Phrase no. (14) which is "head of department diminished my promotion opportunity" came in the $15^{\text {th }}$ place rating (25.3\%, $56.5 \%$ of teaching board members answered the phrase were unsatisfied), while $7.1 \%$ approved on that.

Through the previous display of results and its explanation, the first question of the research was answered and the first aim was achieved which is job satisfaction level of teaching board members of Physical Education faculties.

\section{The answer of research second question:}

Are there statistically shown differences in job satisfaction level of teaching board members in the following variables (age - gender - years of experience - social status - scientific degree)?

To answer this question, the two researchers used the simple linear regression of the five axis results by the following variables indications (age - gender - years of experience - social status - scientific degree).

\section{Table (6)}

The simple linear regression of first axis results by the following variable significance of age, gender, social status, experience, the scientific degree and the university

\begin{tabular}{l|l|l|l|l|l|l|l|l|l}
\hline \hline Variable & $\begin{array}{l}\text { Coefficie } \\
\text { nt } \\
\text { correlatio } \\
\mathrm{n}\end{array}$ & $\begin{array}{l}\text { Degree of } \\
\text { freedom }\end{array}$ & $\begin{array}{l}\text { Regressi } \\
\text { on } \\
\text { Coefficie } \\
\mathrm{nt}\end{array}$ & $\begin{array}{l}\text { Error } \\
\text { rate }\end{array}$ & Beta & $\begin{array}{l}(\mathrm{T}) \\
\text { value }\end{array}$ & $\begin{array}{l}(\mathrm{F}) \\
\text { value }\end{array}$ & $\begin{array}{l}\text { Stable } \\
\text { amoun } \\
\mathrm{t}\end{array}$ & $\begin{array}{l}\text { Contributio } \\
\text { n rate }\end{array}$ \\
\hline \hline Age & 0.159 & 517 & 0.048 & 0.013 & 0.0159 & 3.667 & 13.445 & 1.776 & 2.53 \\
\hline Gender & 0.189 & 517 & $0.107-$ & 0.024 & $0.189-$ & $4.367-$ & 19.071 & 2.011 & 3.56 \\
\hline Social Status & 0.041 & 517 & $0.036-$ & 0.039 & $0.041-$ & $0.930-$ & 0.864 & 1.934 & 0.17 \\
\hline Experience & 0.054 & 517 & 0.0181 & 0.015 & 0.054 & 1.241 & 1.540 & 1.834 & 0.30 \\
\hline $\begin{array}{l}\text { Scientific } \\
\text { Degree }\end{array}$ & 0.059 & 517 & 0.0172 & 0.013 & 0.059 & 1.352 & 1.827 & 1.829 & 0.35 \\
\hline University & 0.323 & 517 & $0.032-$ & 0.004 & $0.323-$ & $8.011-$ & 64.170 & 2.054 & 11.04 \\
\hline \hline
\end{tabular}

The table value of $(\mathrm{R})=0.088$ 
Table (6) shows that there is a correlative relation of statistical significance between age, gender and the university with the first axis (Work Conditions and Environment), the contribution of these variables in the axis of Work Conditions and Environment results reached $2.53 \%, 3.56 \%$ and $11.04 \%$. While there are no statistically shown differences between the social status, experience, and scientific degree of first axis results. The university achieved the highest correlation rate in the first axis variables concerning work environment.

Table (7)

The simple linear regression of second axis results by the following variable significance of age, gender, social status, experience, the scientific degree and the university.

\begin{tabular}{l|l|l|l|l|l|l|l|l|l}
\hline \hline Variable & $\begin{array}{l}\text { Coefficie } \\
\mathrm{nt} \\
\text { correlatio } \\
\mathrm{n}\end{array}$ & $\begin{array}{l}\text { Degree } \\
\text { of } \\
\text { freedom }\end{array}$ & $\begin{array}{l}\text { Regressio } \\
\mathrm{n} \\
\text { coefficien } \\
\mathrm{t}\end{array}$ & $\begin{array}{l}\text { Error } \\
\text { rate }\end{array}$ & Beta & (T) value & $\begin{array}{l}\text { (F) } \\
\text { value }\end{array}$ & $\begin{array}{l}\text { Stable } \\
\text { amount }\end{array}$ & $\begin{array}{l}\text { Contributio } \\
\mathrm{n} \text { rate }\end{array}$ \\
\hline \hline Age & 0.211 & 517 & $0.083-$ & 0.017 & $0.211-$ & $4.910-$ & 24.109 & 1.568 & 4.46 \\
\hline Gender & 0.175 & 517 & $0.129-$ & 0.032 & $0.175-$ & $4.030-$ & 16.242 & 1.594 & 3.05 \\
\hline Social Status & 0.137 & 517 & $0.157-$ & 0.050 & $0.137-$ & $3.135-$ & 9.830 & 1.725 & 1.87 \\
\hline Experience & 0.13 & 517 & $0.056-$ & 0.019 & $0.130-$ & $2.990-$ & 8.939 & 1.507 & 1.70 \\
\hline $\begin{array}{l}\text { Scientific } \\
\text { Degree }\end{array}$ & 0.279 & 517 & $0.105-$ & 0.016 & $0.279-$ & $6.616-$ & 43.775 & 1.624 & 7.81 \\
\hline University & 0.211 & 517 & $0.027-$ & 0.005 & $0.211-$ & $4.920-$ & 24.204 & 1.574 & 4.47 \\
\hline \hline
\end{tabular}

The table value of $(\mathrm{R})=0.088$

Table (7) shows that there is a statistically shown correlation relation between the age, gender, social status, scientific degree and the university with the second axis (salary and incentives). The variables contribution in salary and incentives axis rated in order: $4.46 \%$,
$3.05 \%, 1.87 \%, 7.81 \%$ and $4.47 \%$. While there were no statistically shown differences between experience and results of the second axis. The scientific degree achieved the highest correlation rate in second axis variables concerning salary and incentives.

Table (8)

The simple linear regression of third axis results by the following variable significance of age, gender, social status, experience, the scientific degree and the university.

\begin{tabular}{|c|c|c|c|c|c|c|c|c|c|}
\hline Variable & $\begin{array}{l}\text { Coefficie } \\
\text { nt } \\
\text { correlatio } \\
\text { n }\end{array}$ & $\begin{array}{l}\text { Degree } \\
\text { of } \\
\text { freedom }\end{array}$ & $\begin{array}{l}\text { Regressi } \\
\text { on } \\
\text { coefficie } \\
\text { nt }\end{array}$ & Error rate & Beta & $\begin{array}{l}(\mathrm{T}) \\
\text { value }\end{array}$ & (F) value & $\begin{array}{l}\text { Stable } \\
\text { amoun } \\
\mathrm{t}\end{array}$ & $\begin{array}{l}\text { Contributio } \\
\mathrm{n} \text { rate }\end{array}$ \\
\hline Age & 0.221 & 517 & 0.0593 & 0.012 & 0.221 & 5.142 & 26.440 & 2.233 & 4.87 \\
\hline Gender & 0.118 & 517 & 0.060 & 0.022 & 0.118 & 2.700 & 7.288 & 2.259 & 1.39 \\
\hline Social Status & 0.02 & 517 & 0.0155 & 0.035 & 0.020 & 0.447 & 0.200 & 2.311 & 0.04 \\
\hline Experience & 0.149 & 517 & 0.0441 & 0.013 & 0.149 & 3.432 & 11.720 & 2.271 & 2.23 \\
\hline $\begin{array}{l}\text { Scientific } \\
\text { Degree }\end{array}$ & 0.163 & 517 & 0.0422 & 0.011 & 0.163 & 2.764 & 14.164 & 2.258 & 2.67 \\
\hline University & 0.109 & 517 & 0.009 & 0.004 & $0.109-$ & $2.489-$ & 6.194 & 2.397 & 1.18 \\
\hline
\end{tabular}


Table (8) shows that there is a statistically shown correlation between age, gender, experience, scientific degree and university with the third axis (Performance Quality versus Salary Increase). These variables contribution in the results of performance quality versus salary increase reached in order: $4.87 \%, 1.39 \%$,

\section{Table (9)}

The simple linear regression of fourth axis results by the following variable significance of age, gender, social status, experience, the scientific degree and the university.

\begin{tabular}{l|l|l|l|l|l|l|l|l|l}
\hline \hline variable & $\begin{array}{l}\text { Coefficient } \\
\text { correlation }\end{array}$ & $\begin{array}{l}\text { Degree } \\
\text { of } \\
\text { freedom } \\
\text { on } \\
\text { Coefficie } \\
\text { nt }\end{array}$ & $\begin{array}{l}\text { Error } \\
\text { rate }\end{array}$ & Beta & $\begin{array}{l}\text { (T) } \\
\text { value }\end{array}$ & $\begin{array}{l}\text { (F) } \\
\text { value }\end{array}$ & $\begin{array}{l}\text { Stable } \\
\text { amount }\end{array}$ & $\begin{array}{l}\text { Contributio } \\
\text { n rate }\end{array}$ \\
\hline \hline Age & 0.307 & 517 & 0.1167 & 0.016 & 0.307 & 7.345 & 53.951 & 2.137 & 9.45 \\
\hline Gender & 0.092 & 517 & 0.0657 & 0.031 & 0.092 & 2.102 & 4.417 & 2.260 & 0.85 \\
\hline Social Status & 0.155 & 517 & 0.173 & 0.048 & 0.155 & 3.575 & 12.783 & 2.011 & 2.41 \\
\hline Experience & 0.196 & 517 & 0.0823 & 0.018 & 0.169 & 4.557 & 20.762 & 2.218 & 3.86 \\
\hline $\begin{array}{l}\text { Scientific } \\
\text { Degree }\end{array}$ & 0.223 & 517 & 0.0813 & 0.016 & 0.223 & 5.193 & 26.968 & 2.190 & 4.96 \\
\hline University & 0.037 & 517 & 0.0045 & 0.005 & 0.037 & 0.834 & 0.696 & 2.324 & 0.13 \\
\hline \hline
\end{tabular}

The table value of (R) 0.088

Table (9) shows that there is a statistically reached in order: 9.45\%, 2.41\%, 3.86, 4.96 and shown correlation between age, social status, $1.18 \%$ while there are no statistically shown experience, and scientific degree with the fourth differences between kind, university and third axis (Work Relations). The variables axis results. contribution in results of work relation axis

\section{Table (10)}

The simple linear regression of fifth axis results by the following variable significance of age, gender, social status, experience, the scientific degree and the university.

\begin{tabular}{l|l|l|l|l|l|l|l|l|l}
\hline \hline Variable & $\begin{array}{l}\text { Coefficient } \\
\text { correlation }\end{array}$ & $\begin{array}{l}\text { Degree } \\
\text { of } \\
\text { freedom }\end{array}$ & $\begin{array}{l}\text { Regression } \\
\text { coefficient }\end{array}$ & $\begin{array}{l}\text { Error } \\
\text { rate }\end{array}$ & Beta & $\begin{array}{l}(\mathrm{T}) \\
\text { value }\end{array}$ & $\begin{array}{l}(\mathrm{F}) \\
\text { value }\end{array}$ & $\begin{array}{l}\text { Stable } \\
\text { amount }\end{array}$ & $\begin{array}{l}\text { Contribution } \\
\text { rate }\end{array}$ \\
\hline \hline Age & 0.328 & 517 & 0.0849 & 0.011 & 0.328 & 7.899 & 62.394 & 2.000 & 10.77 \\
\hline Gender & 0.153 & 517 & 0.0743 & 0.021 & 0.153 & 3.520 & 12.390 & 2.052 & 2.34 \\
\hline $\begin{array}{l}\text { Social } \\
\text { Status }\end{array}$ & 0.043 & 517 & 0.033 & 0.033 & $0.043-$ & $0.986-$ & 0.972 & 2.219 & 0.19 \\
\hline Experience & 0.27 & 517 & 0.0769 & 0.012 & 0.270 & 6.370 & 40.572 & 2.031 & 7.28 \\
\hline $\begin{array}{l}\text { Scientific } \\
\text { Degree }\end{array}$ & 0.241 & 517 & 0.0599 & 0.011 & 0.241 & 5.644 & 31.759 & 2.037 & 5.80 \\
\hline University & 0.438 & 517 & $0.036-$ & 0.003 & $0.438-$ & $11.082-$ & 122.82 & 2.370 & 19.20 \\
\hline \hline
\end{tabular}

The table value of $(R)=0.088$ 
Table (10) shows that there is a statistically shown correlation between gender, scientific degree and university with the fifth axis (Promotion System). Variables contribution in results of performance quality versus salary increase axis reached in order: $4.87 \%, 1.39 \%$, $2.22 \%, 2.67 \%$ and $1.18 \%$ while there is no statistically shown differences between the social status and fifth axis results.

What is previously mentioned shows the nature of the relation between job satisfaction and some variables (age - gender - years of

Table (11)

The Relative Weight of Job Satisfaction Axis

\begin{tabular}{l|l|l|l|l|l|l|l|l}
\hline \hline No. & Axis & $\mathrm{m}$ & $\mathrm{S} \pm$ & Mediator & $\begin{array}{l}\text { Skew } \\
\text { ness }\end{array}$ & $\begin{array}{l}\text { Total } \\
\text { marks }\end{array}$ & $\begin{array}{l}\text { Relative } \\
\text { Weight }\end{array}$ & $\begin{array}{l}\text { Axis } \\
\text { order } \\
\text { in the } \\
\text { scale }\end{array}$ \\
\hline \hline 1 & $\begin{array}{l}\text { Work } \\
\text { Environment }\end{array}$ & 1.82 & 0.06 & 2 & 2 & 18876 & $36.37 \%$ & 1 \\
\hline 2 & $\begin{array}{l}\text { Salary } \\
\text { incentives }\end{array}$ & 1.4 & 0.08 & 1 & 1 & 8991 & $17.32 \%$ & 5 \\
\hline 3 & $\begin{array}{l}\text { Performance } \\
\text { Quality } \\
\text { versus Salary } \\
\text { Increase } \\
4\end{array}$ & 2.34 & 0.17 & 2 & 2 & 16118 & $31.1 \%$ & 3 \\
\hline 5 & $\begin{array}{l}\text { Work } \\
\text { Relations }\end{array}$ & 2.35 & 0.08 & 2 & 2 & 16738 & $32.25 \%$ & 2 \\
\hline System & 2.56 & 0.13 & 2 & 2 & 14310 & $27.57 \%$ & 4 \\
\hline \hline
\end{tabular}

Table (11) shows that the relative weight of the five axis ranged from $(27.57 \%-36.37 \%)$ where the first axis came in the first place rating $36.37 \%$, followed by work relation axis in the second place rating $32.25 \%$, while the promotion system axis came in the fourth place rating $27.57 \%$, in the fifth and last place came salary and incentives axis rating $17.32 \%$. this indicated the weak level of job satisfaction of teaching board members concerning salary and incentives.

Table (11) also shows that the relative weight of job satisfaction of teaching board members in Physical Education faculties of Egyptian universities reached $36.38 \%$ which indicates the weak job satisfaction according to this scale. experience - social status - and scientific degree) of teaching board members of Physical Education faculties? The correlation differed from variable to another which agrees with both studies of (5) and (6).

The answer of the third question:

What are the most important elements that achieve job satisfaction of teaching board members of Physical Education faculties?
Through what previously displayed the two researchers had answered the third question in relation to the third aim of the research.

The most important elements that achieve job satisfaction of teaching board members of Physical Education faculties.

\section{Research Most Important Conclusions:}

1- The job satisfaction of teaching board members of Physical Education faculties studied in the research came weak rating $36.38 \%$.

2- Work Environment axis came in the first place in job satisfaction of teaching board members rating $36.37 \%$, while in the fifth and last place came salary and incentives axis rating $17.32 \%$. 


\section{Recommendations:}

- To put strategies in order to raise job satisfaction of teaching board members.

\section{References:}

\section{First: Arabic References:}

1- Sanaa Ahmed Kamal Abdel Salam (2005): "The Academic Factors related to Job Satisfaction of University Professor, A Field Study on faculties of Education ". A Master thesis, faculty of Education, Ain Shams University.

2- Haifaa Nagib Shraida (2002): Some Factors affecting job satisfaction level of teaching board members concerning the services provided to them in Yarmok University, Faculty of Education magazine, issue no. (30).

3- Abdo Ahmed Mohammed Hussein (2006): Job Satisfaction of Teaching Board Members and its scientific productivity in Eden University, Ph. D thesis, Faculty of Education, Eden University.

4- Gawad Mohammed El-Sheikh, Aziza Abdel Allah Shrir (2007): Job Satisfaction and its relation with some teachers demographic variables" the Islamic University magazine, Vol. $16,1^{\text {st }}$ issue, January 2007.

5- Elkasasia Mohamad and Elhawamda Nidal Saleh (2000): The effect of organizational trust and the participation of decision making in satisfaction of members of staff of education in Moata University. Journal of Moata of research and studies ( human and social science), Vol. 15, $6 ; 141: 195$.

\section{Second: Foreign References:}

6- Truell, Price, \& etal (1998): Implementers Teacher Job Satisfaction in School management. Santiago, preiffer. U.S.A, Pl.

7- Testa, Mark R. (2001): Organized alionl Commitment, Job Satisfaction, and effort in service environment, Journal of Psychology, Mar, Vol. (135), Issue (2).

8- Carsten, J. M., \& Spector, P. E. (1987). Unemployment, job satisfaction, and employee turnover: A meta-analytic test of the Muchinsky model. Journal of Applied Psychology, 72, 374-381.

9- Samir Nasr El din (2006). Job satisfaction of member of staff of education in Saudi Universities. Published in midline. www.minshawi.com/node.

10- Haekel Taha Mohammed (2007). Measuring factors of staff and their assistants in Yaman universities and its effects in the outcome of the education process Msc study in Sanaaand Adan universities. www.minshawi.com/node. 